\title{
Teologi Multikultural sebagai Respon terhadap Meningkatnya Eskalasi Politik Identitas di Indonesia
}

\author{
Multicultural Theology as a Response to the Increasing Escalation of Identity \\ Politics in Indonesia
}

\author{
Obet Nego \\ STT Ebenhaezer, Tanjung Enim \\ obetnego82@gmail.com
}

\begin{abstract}
Article Info Abstract

Submitted:

August 28, 2020

Review Start:

Sept 2, 2020

Accepted:

Oct 5, 2020

Keywords:

Identity, Politics, Multicultural, Theology

This paper discusses the emergence of a serious threat from the practice of identity politics in Indonesia. As a large nation, Indonesia is a heterogeneous nation in religion and ethnicity, so the emergence of Identity Politics cannot be avoided. A democracy that is built on the spirit of national unity and integrity is in danger of being damaged and destroyed by evil political passions. The threat was then responded to by multicultural theology, in the form of a theological formula to base Christian attitudes in relations with people of different religions and ethnicities. Writing this article uses a qualitative approach with the literature study method in collecting data related to trends in Identity Politics and Multicultural Theology. The presence of Multicultural Theology in the world of politics in Indonesia will create a political process that is healthy and dignified, by respecting each other regardless of their background.
\end{abstract}

[Tulisan ini membahas tentang munculnya ancaman yang serius dari praktik Politik Identitas di Indonesia. Sebagai bangsa yang besar, Indonesia adalah bangsa yang heterogen secara agama dan etnisitas, sehingga munculnya Politik Identitas tidak bisa dihindari. Demokrasi yang dibangun berdasarkan semangat persatuan dan kesatuan bangsa, terancam rusak dan hancur oleh karena nafsu politik yang jahat. Ancaman tersebut kemudian direspon dengan Teologi Multikultural, berupa formula teologis untuk mendasari sikap Kristen dalam relasinya dengan sesama yang berbeda religi dan etnik. Pendekatan kualitatif deskriptif digunakan di dalam artikel ini. Metode studi literatur dipakai dalam mengumpulkan data-data yang terkait dengan tren Politik Identitas dan Teologi Multikultural. Hadirnya Teologi Multikultural di dalam dunia politik di Indonesia, akan menciptakan proses berpolitik yang sehat dan bermartabat, dengan saling menghargai sesama apapun latar belakangnya.] 


\section{PENDAHULUAN}

$\mathrm{N}$ Tegara Kesatuan Republik Indonesia secara faktual merupakan bangsa yang besar. Bukan diukur dari luasnya cakupan wilayah, namun kekayaan kultur di dalamnya. Indonesia adalah negara yang terdiri dari beragam bangsa, yang terdiri dari banyak kelompok identitas partikular yang sangat bervarian. Tidak hanya beragam bangsa, Indonesia juga memiliki kelompokkelompok identitas partikular yang cukup banyak. Hal ini sepemikiran dengan Bhikhu Parekh, bahwa, "just as society with several religions on langguages is multi religious or multilinggual, asosiety containing several culteres is multicultural". ${ }^{1}$ Dalam hal ini Indonesia bisa disebut sebagai bangsa yang Multikultural. Kultur (culture) adalah worldview yang diyakini oleh individu maupun kelompok yang dijadikan landaran dalam berperilaku. ${ }^{2}$ Adanya keberagaman kultur tersebut, satu sisi Indonesia memiliki potensi budaya bangsa yang besar, namun di sisi lain bisa berpotensi sebagai pemecah dan pemicu konflik horizontal, termasuk di dalam berdemokrasi.

Proses demokrasi di Indonesia merupakan proses berdemokrasi yang tidak bisa dipisahkan dari orientasi identitas agama dan etnis. Berdasarkan pengalaman sejarah, Politik Identitas di Indonesia sudah lama ada. Menurut Geertz setelah kemerdekaan muncullah afeksi terhadap primordialisme yang dipicu oleh perbedaan identitas masing-masing kelompok budaya, agama, dan ranah geografis. ${ }^{3}$ Di paskah reformasi, dengan munculnya era 'kebebasan', demokrasi di Indonesia mendapatkan angin segar yang selama ini 'dibekukan' oleh pemerintahan Orde Baru. Realitasnya, angin segar tersebut tidak selalu menghasilkan kebebasan yang diharapkan, persoalan baru pun muncul berupa konflik horizontal yang disebabkan oleh identitas pertikular yang dipolitisasi.

Salah satu contoh peristiwa yang sangat menyita perhatian bangsa Indonesia bahkan dunia, yaitu kontestasi Pilkada Jakarta di tahun 2017. Peristiwa ini berawal dari pidato Gubernur Jakarta yaitu Basuki Tjahaja Purnama atau Ahok di Pulau Seribu yang dinilai telah melecehkan agama Islam. Polemik ini akhirnya berbuntut panjang dengan munculnya demonstrasi-demonstrasi yang menuntut Ahok supaya dibawa ke meja hijau dan dihukum seberat-beratnya. Berawal dari peristiwa inilah, seolah-olah telah terjadi pergulatan antara masyarakat pribumi dan non pribumi dalam proses Pilkada. Dalam hal ini pasangan Ahok - Djarot menjadi potret identitas dan representasi non muslin dari etnis Tionghoa dan Anis-Sandi dari Muslim pribumi. ${ }^{4}$

Bawaslu telah mencatat rentetan peristiwa Pilkada serentak di tahun 2018 yang dipengaruhi oleh Politik Identitas, dan semua itu dipengaruhi oleh peristiwa Pilkada di Jakarta 2017. ${ }^{5}$ Harus diakui, angka praktik politik identitas semakin naik di sejumlah daerah di Indonesia pasca Pilkada Jakarta. Isu-isu identitas menjadi senjata ampuh untuk digunakan oleh pihak-pihak yang terlibat sebagai kontestan politik untukmembangun citra negatif kompetitor politiknya. ${ }^{6}$ Pada saat Pemilu Presiden

${ }^{1}$ Bikhu Parekh, (Terj) Rethinking Multiculturalism, Keragaman Budaya Dan Teori Politik (Yogyakarta: Kanisius, 2008).17

2 Stepen Grunlan, ed., Christian Perspektif on Sociology (Grand Rapid, Michigan: Zondervan Publishing House, 1982); Lotnatigor Sihombing, Kultus Dan Kultur: Sikap Etis Kristen Terhadap Kebudayaan (Batu: Sekolah Tinggi Theologia "I-3," 1997).

3 Juwono Sudarsono, Pembangunan Politik Dan Perubahan Politik, Pertama (Jakarta: Gramedia, 1976). 15,20

${ }^{4}$ Juhana Nasrudin, "Politik Identitas dan Identitas Kebangsaan,” Al-Karimah, vol. 5, no. 9 (2018): 94 137.

5 Bawaslu, "Potensi Penggunaan Suku, Agama, Ras dan Antar Golongan dalam Pemilihan Kepala Daerah Serentak 2018” (Jakarta, 2017).

${ }^{6}$ M Mietzner, "Reinventing Asian Populism: Jokowi’s Rise, Democracy, and Political Contestation in Indonesia. Policy Studies,” 2015, accessed April 20, 2020, http://search.ebscohost.com/login.aspx?direct=true \&db=a9h\&AN=102181521\&site=ehost-live \&scope=site. 
dan Wakil Presiden pun isu politik berbasis identitas juga menjadi komoditi politik dan menyebabkan ketegangan di publik. Figur Joko Widodo sebagai calon presiden dihantam berbagai isu yang berbau identitas, tidak hanya Joko Widodo, kompetitornya, Prabowo Subianto pun tidak luput dari isu agama. Maka tidak mengherankan lagi, hiruk pikuk pesta demokrasi 2019 tersebut mulai terjebak dengan suasana politik identitas. ${ }^{7}$ Sehingga, di dalam suasana politik tersebut terdapat tindakantindakan destruktif yang tercipta oleh karena radikalisme agama yang dimiliki oleh setiap agama di Indonesia. Novalina mengutarakan bahwa tidak sedikit tindakan-tindakan radikal (verbal maupun fisik) yang muncul dilatarbelakangi oleh politik kotor, bukan dokrin keyakinan semata. ${ }^{8}$

Atmosfer politik demikianlah yang membuat demokrasi Indonesia mengalami kemunduran. Cita-cita luhur dari proses berdemokrasi yang beradab dan berdaulat, dengan memilih pemimpin yang memiliki kualifikasi yang berintegritas dan berkualitas, akhirnya hanya dipenuhi dengan ujaran kebencian yang hanya bisa menciptakan permusuhan bahkan menimbulkan kehancuran antar-anak bangsa. ${ }^{9}$ Akibatnya, pelaksanaan pesta demokrasi di tanah Air jauh dari cita-cita luhurnya. Implikasi dari mengkristalnya isu-isu perbedaan tersebut sangat mengancam kehidupan demokrasi dan keutuhan bangsa. Yang lebih menakutkan lagi, Politik Identitas sangat berpotensi menimbulkan instabilitas politik dan disintegrasi bangsa. Keprihatinan ini, telah berdampak bagi sejumlah daerah di Indonesia, khususnya daerah-daerah 'kantong' Kristen. Misalnya, di Manokwari-Papua. Saputra memaparkan bahwa politik identitas yang terjadi di kota Manokwari merupakan perkembangan politik di Papua pada umumnya, pasca reformasi. Di mana sepanjang pemerintahan Orde Baru, rakyat Papua mengalami kekejaman militer (masa Daerah Operasi Militer). Bahkan terpinggirkan oleh para pendatang, di sektor ekonomi dan pemerintahan."10 Akibatnya radikalisme muncul dan mengancam kerukunan umat beragama, contohnya kasus perlawanan terhadap pembangunan Masjid di Distrik Andai pada tahun 2015 lalu oleh sejumlah tokoh Gereja Kristen lokal di Manokwari. Pertarungan identitas untuk menunjukkan supremasi Kristen juga diperlihatkan dengan mengajukan draf rancangan Perda Manokwari. ${ }^{11}$

Selain kota Manokwari, di provinsi NTT, pola dari Politik Identitas pun 'diadopsi' oleh elitelit politik di sana. Buntut panjang dari peristiwa Pilkada di Jakarta, atau lazim disebut Ahok Effect. Fenomena tersebut semakin 'panas' takkala Ahok mendulang kekalahan. Tolo menuturkan bahwa simpatisan Ahok yang hampir semua pemilih Kristen adalah potensi suara bagi para politisi di NTT. Peristiwa Pilkada di NTT dijadikan kesempatan untuk membalas dendam atas kekalahan Ahok di Jakarta. Dengan cara mendiskreditkan para kandidat yang berasal dari partai-partai yang kontra Ahok. ${ }^{12}$ Efek tersebut menciptakan sentimen-sentimen agama dalam berpolitik, terlebih terhadap agama Islam. Sehingga dalam menentukan pilihan politiknya selalu berafiliasi kepada agama tertentu.

Berangkat dari keprihatinan di atas, diperlukan sebuah strategi khusus sebagi solusi dalam memecahkan persoalan segregasi sosial yang diakibatkan oleh Politik Identitas, yaitu Teologi

7 Ari Ganjar Herdiansah, "Politisasi Identitas Dalam Kompetisi Pemilu Di Indonesia Pasca 2014," Jurnal Bawaslu, vol. 3, no. 2 (2017): 169-83.

${ }^{8}$ Martina Novalina, "Spiritualitas Orang Kristen Dalam Menghadirkan Kerajaan Allah Di Tengah

Tantangan Radikalisme,” Jurnal Teologi Kontekstual Indonesia, vol. 1, no.1 (2020): 26-37, https://doi.org/10.46445/jtki.v1i1.293.

${ }^{9}$ M.G. Noviarizal Fernandez, "Politik Identitas Merusak Demokrasi," 2019, https://kabar24.bisnis.com/read/20190102/15/874543/politik-identitas-merusak-demokrasi.

10 Muhammad Ali Saputra, "Menguatnya Politik Identitas dan Problem Kerukunan Beragama di Manokwari," Jurnal Mimikri, vol. 3, no. 1 (2017): 15-27.

${ }^{11}$ Saputra, "Menguatnya Politik Identitas dan Problem Kerukunan Beragama di Manokwari,".

12 Emilianus Yakob Sese Tolo, "Di Bawah Bayang-Bayang Ahok: Politik Identitas Dalam Pemilu Di NTT," Tirto.Id, 2019. 
Multikultural. Prinsip-prinsip Teologi Multikultural dipandang sebagai instrumen yang dapat diandalkan dalam merespon ancaman dari Politik Identitas, yaitu instabilitas politik dan disintegrasi bangsa, sehingga integrasi bangsa secara demokratis dapat direkatkan. Selain itu, melalui tulisan ini penulis akan menyajikan bagaimana figur politisi yang memegang ideologi multikultural yang kuat.

\section{METODE}

Dengan mengamati dan menganalisis rentetan peristiwa politik di Indonesia lima tahun ke belakang, baik melalui media digital maupun media cetak terkait dengan tren politisasi identitas dalam politik dan membuat rancang bangun Teologi Multikultural, maka pendekatan yang digunakan adalah kualitatif deskriptif dengan menggunakan metode studi literatur. ${ }^{13}$ Fokusnya adalah pada kajian tren Politik Identitas dan Teologi Multikultural yang berasal dari sumber-sumber pustaka yang disistematiskan ke dalam uraian kerangka penulisan sebagai berikut: pertama, dimulai dengan memaparkan fakta-fakta dari tren Politik Identitas di Indonesia berikut dengan dampak yang diakibatkannya. Kedua, mendeskripsikan rancang bangun dari Teologi Multikultural beserta dengan dasar teologisnya sebagai respon terhadap ancaman dari Politik Identitas tersebut. Ketiga, berangkat dari kajian-kajian tersebut, maka selanjutnya dibuat model politisi yang dapat merepresentasikan figur politisi yang berjiwa multikutural. Studi literatur dipakai oleh penulis untuk menelusuri setiap perkembangan terkait dengan tren Politik Identitas dan Teologi Multikultural. Teknik pengumpulan data primer maupun sekunder, menggunakan teknik kepustakaan dan literatur terkait, yaitu sumber pustaka berupa buku-buku, literatur online berupa e-book, artikel/e-journal terbaru, dan majalah online.

\section{PEMBAHASAN}

\section{Pengertian Politik Identitas}

Identitas diri hakikatnya merupakan suatu perasaan yang subjektif mengenai dirinya sendiri yang di dalamnya mencakup ciri, sifat atau karakter. ${ }^{14}$ Sedangkan menurut Suparlan yang dikutip Romli menyebutkan bahwa, "identitas adalah pengakuan terhadap orang-orang tertentu atau kelompok tertentu yang memiliki rantai karakteristik tertentu yang menjadi satu kesatuan yang menandai mereka untuk dimasukkan dalam kelompok atau komunitas tertentu." ${ }^{15}$ Menurut Castells yang dikutip oleh Idris Hemay dan Aris Munandar, terdapat tiga asal usul identitas, yaitu legitimizing identity sebagai identitas sah yang bisa dicontohkan akan adanya dominasi dan otoritas; Resistance identity yang identik dengan politik identitas; terakhir, project identity adalah identitas proyek dengan contoh orientasi kelompok gender seperti feminisme. ${ }^{16}$

Terkait dengan Politik identitas, sebenarnya tidak diketahui siapa pertama kali yang menciptakan istilah dari Politik Identitas sampai hari ini. Awalnya, Politik identitas lahir dari sebuah bentuk reaksi dari ketidakadilan yang dialami kelompok minoritas karena arogansi kelompok mayoritas dalam sosial masyarakat. ${ }^{17}$ Romli mengutip Heller dan Punsher terkait Politik Identitas,

${ }^{13}$ Sonny Eli Zaluchu, "Strategi Peneltian Kualitatif dan Kuantitatif di Dalam Penelitian Agama," Evangelical, vol. 4, no. 1 (2020): 28-38.

${ }^{14}$ James P. Chaplin, Kamus Lengkap Psikologi, Terjemahan (Jakarta: Raja Grafindo Persada, 2011).

${ }^{15}$ Lili Romli, "Political Identity and Challanges for Democracy Consolidation in Indonesia," Jurnal Politik Indonesia, vol. 4, no. 1 (2019).

${ }^{16}$ Idris Hemay and Aris Munandar, "Politik Identitas dan Pencitraan Kandidat Gubernur Terhadap Perilaku Pemilih," Jurnal Politik: Kajian Politik dan Masalah Pembangunan, vol. 12, no. 1 (2016): 37-48.

17 Ahmad Syafii Maarif, Politik Identitas dan Masa Depan Pluralisme Kita, ed. Martin Sinaga, 1st ed. (Jakarta: Democracy Project, 2012). 
"define identity politics as a concept and political movement that focused on their difference as the main political category. This thing appeared because of the failure of the grand narrative, like the idea of freedom and tolerance. Therefore, differential politics became a new name from identity politics; racism, bio-feminism and ethnical conflict. "18

Habibi juga memberikan pengertian lain terhadap Politik Identitas, "Politik identitas sendiri merupakan konsep baru dalam kajian ilmu politik. Politik identitas adalah nama lain dari biopolitik dan politik perbedaan. Biopolitik mendasarkan diri pada perbedaan-perbedaan yang timbul dari perbedaan tubuh." 19 Karena itu para akademisi ilmu politik berusaha menyusun kembali pengertian dari Politik Identitas dengan lebih sederhana dan logis. Misalnya saja penjelasan Heller yang dikutip Haboddin, menyebutkan politik identitas adalah: "gerakan politik yang fokus perhatiannya adalah perbedaan sebagai suatu kategori politik yang utama." ${ }^{20}$ Menurut Morowitz, ahli politik dari Universitas Duke, menuturkan: "Politik identitas adalah memberian garis yang tegas untuk menentukan siapa yang akan disertakan dan siapa yang akan ditolak. Karena garis-garis penentuan tersebut tampak tidak dapat dirubah, maka status sebagai anggota bukan anggota dengan serta merta tampak bersifat permanen." ${ }^{21}$ Dengan demikian, penulis akan mengategorikan intoleransi ke dua dimensi, yakni intoleransi politik dan intoleransi religius kultural.

\section{Munculnya Intoleransi Politik}

Proses berdemokrasi di Indonesia telah berusia dua dekade pascareformasi. Di usia yang cukup dewasa ini, wajar jika proses berdemokrasi diharapkan akan berproses lebih baik dan maju. Namun, patut disayangkan kualitas demokrasi di Indonesia 'terkesan' mengalami kemunduran. Hal ini diperkuat oleh data dari hasil survei penelitian The Economist Intelligence Unit tentang kebebasan berdemokrasi suatu negara, yang menyebutkan bahwa Indonesia mengalami penurunan peringkat dari 48 ke peringkat 68 dunia. ${ }^{22}$

Harus diakui sejak 2014, dinamika berdemokrasi di Indonesia selalu diwarnai oleh isu-isu sentimen partikular dalam setiap kegiatan kampanyenya, dimana narasi emosionalitas lebih mendominasi dari narasi rasionalitas. Casram mengidentifikasikan dikotomi antara pemilih yang rasional dan emosional. Pemilih yang rasional diidentikkan sebagai educated people, yaitu orangorang yang setia menggunakan analisis intelektualitasnya dalam beragama, dan cenderung mengabaikan unsur perasaan, simbol-simbol keagamaan dan lebih inklusif terhadap keragaman. Berbanding terbalik dengan jenis pemilih emosional yang diidentikkan sebagai ordiniary people, yaitu orang-orang membatasi makna keagamaan hanya dengan simbol-simbol agama tanpa menggunakan analisis intelektualitasnya. Implikasinya, mereka sangat eksklusif dan intoleran dengan identitas agama lain, bahkan cenderung menggunakan kekerasan dalam komunikasi sosial

${ }^{18}$ Lili Romli, "Political Identity and Challanges for Democracy Consolidation in Indonesia."

19 Muhammad Habibi, "Analisis Politik Identitas Di Indonesia (Identity Politics in Indonesia)" (Samarinda, 2017).

${ }^{20}$ Muhtar Haboddin, "Menguatnya Politik Identitas Di Ranah Lokal," Studi Pemerintahan, vol. 3, no. 2012 (2012): 116-34.

${ }^{21}$ Donald L. Morowitz, "Demokrasi Pada Masyarakat Majemuk," in Nasionalisme, Konflik Etnik dan Demokrasi, ed. Mars F Plattner and Larry Diamond (Bandung: ITB Pres, 1998).

22 Burhanuddin Muhtadi, "Menguatnya Intoleransi Dan Politik Identitas," Media Indonesia, last modified 2018, accessed April 20, 2020, https://mediaindonesia.com/read/detail/205379-menguatnyaintoleransi-dan-politik-identitas. 
dan politiknya. Oleh karena itu, tipe kelompok ini sangat mudah digerakan dan ditunggangi oleh kepentingan-kepentingan politik yang mengatasnamakan agama. ${ }^{23}$

Dengan demikian, tren politik Identitas dalam momen elektoral, baik Pilpres maupun Pilkada, masyarakat kerap termakan narasi negatif. Cara ini jelas merusak sistem berdemokrasi yang dikenal dengan bebas berpendapat, termasuk memilih pemimpin berdasar kualifikasi pemimpin yang ideal, tanpa menilai etnis atau religi yang bersangkutan. ${ }^{24}$

Dalam pandangan Sulivan, Piereson dan Marcus dalam kutipan Zhafira, sebuah negara demokrasi, dapat mengalami perpecahan oleh karena konflik. Namun jika selama penduduknya bersama-sama mendukung asas-asas demokrasi, seperti semua warga dapat berpartisipasi dalam kegiatan politik dan memiliki hak berbicara di depan umum, negara tersebut dipastikan dapat mempertahankan stabilitas sosial dan politiknya. ${ }^{25}$ Di sisi lain, hasil analisis Eisenstein dan Clark membuktikan bahwa nilai-nilai demokrasi terbukti sangat rendah justru di negara yang politiknya bersistem demokrasi. Hal ini disebabkan oleh arogansi dan dominasi mayoritas yang mengabaikan nilai toleransi dalam berbangsa. ${ }^{26}$

Sikap menentang 'kebebasan' sipil dalam kegiatan politik, siapapun dan apapun latar belakangnya merupakan ancaman dalam pelaksanaan demokrasi di bumi Pancasila ini. Dengan kata lain, pembatasan bahkan menghilangkan hak-hak politik seseorang berdasarkan perbedaan identitas adalah tindakan intoleran yang bertentangan dengan konstitusi negara Republik Indonesia. ${ }^{27}$

\section{Munculnya Intolerasi Religius Kultural}

Di Indonesia Politik Identitas dengan memanfaatkan isu SARA memang sangat berpotensi mematik konflik dan perpecahan. Hal ini dipicu oleh masih kuatnya sentimen-sentimen kedaerahan, primordialisme serta rendahnya toleransi tentu harus segera diatasi untuk mencegah disintegrasi bangsa. ${ }^{28}$ Selanjutnya, Endang menjelaskan bahwa: "Politik identitas khususnya agama memang tidak pernah mati dalam arena politik di negeri ini. Momentum pemilihan Gubernur Jakarta yang baru saja usai, adalah contoh nyata bagi pembenaran argumentasi tersebut. Ketika Identitas agama, muncul menjadi sebuah kekuatan politik," ${ }^{29}$ Terkait dengan masalah ini, Sanur menjelaskan bahwa praktik politik identitas di Indonesia semakin menguat ketika terjadi kontestasi politik. Ditambahkan oleh M. Imdadun Rahmat (Komnas HAM) melaporkan ada kenaikan yang cukup signifikan terkait kasus intoleransi dalam peristiwa politik. Komnas HAM mencatat pada tahun 2015 ada 87 laporan,

${ }^{23}$ Casram, "Membangun Sikap Toleransi Beragama Dalam Masyarakat Plural," Wawasan: Jurnal Ilmiah Agama dan Sosial Budaya, vol. 1, no. 2 (2016): 190.

${ }^{24}$ Erlangga Pratama, "Politik Identitas: Ancaman Dalam Pilkada 2020," Jurnal Intelijen.Net: Verba Volant Scripta Manent, 2020, accessed April 20, 2020, https://jurnalintelijen.net/2020/01/15/politik-identitasancaman-dalam-pilkada-2020/.

${ }^{25}$ Ananda Zhafira, "Efek Moderasi Kepercayaan Politik Terhadap Hubungan Antara Religiusitas Islam Dan Intoleransi Politik,” Jurnal Psikologi Sosial, vol. 15, no. 2 (2017): 122.

${ }^{26}$ M. Eisenstein \& A. Clark, "Explaining Differing Democratic Norm Commitment: Rethinking the Religion- Psychological Security-Democratic Norm Support Connection," Politics and Religion, vol. 10, no. 4 (2017): 753-85, https://doi.org/10.1017/S175504831700030X.

${ }^{27}$ J.L. Sullivan; G.E. Marcus; J.E.Piereson, “An Alternative Conceptualization of Political Tole- Rance: Illusory Increases 1950s- 1970s.," The American Political Science Review, vol. 73, no. 2 (1979): 781-794; dalam Zhafira, "Efek Moderasi Kepercayaan Politik Terhadap Hubungan Antara Religiusitas Islam Dan Intoleransi Politik."

${ }^{28}$ Debora Sanur L, "Rekonsiliasi Politik Identitas di Indonesia," Majalah Info Singkat (Jakarta, Mei 2017), 2.

${ }^{29}$ Endang Sari, "Kebangkitan Politik Identitas Islam Pada Arena Pemilihan Gubernur Jakarta," Kritis, vol. 2, no. 2 (2016): 145-56. 
kemudian meningkat lagi pada tahun 2016 menjadi 97 laporan. Setahun berikutnya, eskalasi politik yang berbau intoleran naik tajam dalam kontestasi Pilkada DKI Jakarta di tahun 2017. ${ }^{30}$

Menurut Nathaniel permainan para elit politik yang 'memperalat' sentimen primodial sebagai senjata politik, tidak disadari oleh masyarakat lapis bawah atau lazim disebut sebagai grassroot people. Isu yang berbau intoleran ini tidak hanya dipakai dalam kepentingan elektoral tetapi telah menjadi agenda politik kelompok elit dalam tata laksana bernegara. ${ }^{31}$ Menurut Erlangga, praktik politik identitas yang berlebihan akan menciptakan fasisme bahkan yang lebih buruk lagi yaitu separatisme. Apalagi masyarakat yang sudah terasimilasi dengan identitas tertentu, berpotensi dimanfaatkan untuk agenda politik tertentu. Terlebih lagi hegemoni di dalam politik di Indonesia yang berorientasi memunculkan negara mono-identitas, secara perlahan namun pasti akan menghilangkan identitas keragaman bangsa ini. ${ }^{32}$

Tidak jarang upaya mono-identitas tersebut menciptakan konflik-konflik antar pemeluk agama. Melalui kacamata pengamatan Geertz yang dikutip Baidi, catatan sejarah terkait dengan konflik di Indonesia acapkali disulut oleh gesekan-gesekan identitas agama, selain identitas etnis. Di mana hal tersebut dinilai mampu menciptakan disintegrasi bagi bangsa yang majemuk ini. ${ }^{33}$

\section{Pengertian Teologi Multikultural}

Secara etimologi istilah "Teologi" berasal dari kata Yunani: theos yang artinya Allah dan logos artinya pernyataan yang rasional. ${ }^{34}$ Secara literal "teologi" berarti "berbicara tentang Allah atau apa yang dipikirkan atau dikatakan tentang Allah." 35 Macquarrie mendefinisikan sebagai berikut: "Teologi adalah suatu kajian yang berusaha menyatakan inti iman dalam bahasa yang sangat jelas dan sepadan. Teologi mensyaratkan partisipasi dan refleksi dari suatu komunitas iman." 36 Erikson memberikan definisi teologi dalam bukunya Teologi Kristen vol. I, ia menyebutkan bahwa Teologi usaha untuk menginterpretasikan dan merumuskan secara rasional hal yang berkaitan dengan ajaran iman Kristen, bersumber dari Kitab Suci dan diimplementasikan ke dalam konteks budaya, sosial dan persoalan manusia masa kini. ${ }^{37}$ John M. Frame juga menjelaskan Teologi dengan pernyataan: "the application of the Scripture, by person, to every area of life" 38

Selanjutnya adalah istilah Multikutural atau multi budaya. Multikultural (Multiculture) dibentuk dari kata multi (banyak), culture (budaya). ${ }^{39}$ Will Kymlicka berpendapat seperti yang dikutip oleh Ibrahim, "Multibudaya merupakan suatu pengakuan, penghargaan dan keadilan terhadap etnik

${ }^{30}$ Debora Sanur L, "Rekonsiliasi Politik Identitas di Indonesia.”2.

31 Felix Nathaniel, "Politik Identitas Tetap Buas, Masyarakat Bawah Kena Imbas," Tirto.Id, 2019, accessed April 20, 2020, https://tirto.id/politik-identitas-tetap-buas-masyarakat-bawah-kena-imbas-emEE.

32 Pratama, "Politik Identitas: Ancaman Dalam Pilkada 2020."

33 Cifford Geertz, "Religion in Java; Conflict and Integration," in Sociology of Religion: Selected Readings, ed. Roland Robertson (England: Penguine Book, 1971), 165-217; dikutip oleh Baidi, "Agama dan Multikulturalisme: Pengembangan Kerukunan Masyarakat Melalui Pendekatan Agama,” Millah, 2010, 2.

${ }^{34}$ Charles C. Ryrie, Teologi Dasar 1 (Yogyakarta: ANDI, 2017), 15.

35 Daniel Ronda, Dasar Teologi Yang Teguh: Panduan Teologi Sistematika Di Perguruan Tinggi, I (Makasar: STT Jaffray, 2013).

${ }^{36}$ John Macquarrie, Principle of Christian Theology (London: SCM Press, 1996); Happy Susanto,

"Kritisisme Sejarah Teologi Barat," Tsaqafah, vol. 7, no. 2 (2011): 299,

https://doi.org/10.21111/tsaqafah.v7i2.11.

${ }^{37}$ Millar J. Erikson, Teologi Kristen Vol. 1 (Malang: Gandum Mas, 2004), 27-28.

${ }^{38}$ John M. Frame, Systematic Theology: An Introduction to Christ Belief (New Jersey: P \& R, 2013).

${ }^{39}$ Afik Ahsanti, Teologi Multikultural: Telaah Atas Pemikiran Tokoh Indonesia Komarudin Hidayat (Yogyakarta, 2015), 5. 
minoritas baik yang menyangkut hak-hak universal yang melekat pada hak-hak individu maupun komunitasnya yang bersifat kolektif dalam mengekspresikan kebudayaannya." ${ }^{40}$

Berkaca dari pandangan-pandangan tersebut di atas, sangat dimungkinkan bahwa Alkitab dapat menjadi pijakan spiritualitas multikultural tersebut. Dengan demikian kecenderungan manusia untuk memiliki truth claim yang berpotensi untuk 'meledak' dan destruktif itu, dapat dinetralisir dengan mencari titik temu bagi beragamnya nilai-nilai fundamental berbagai kelompok agama dan etnis yang pluralistik, dengan menciptakan mutual understanding dalam relasi antar agama. Tentunya dengan mencairkan sekat-sekat teologis dan kultur yang selama ini telah terkristal oleh sejarah kehidupan manusia. Secara definisi Sudarmanto mengemukakan bahwa Teologi Multikultural adalah rumusan teologi yang dibangun secara sistematis dari interpretasi dua Perjanjian di Alkitab (PL dan PB) tentang bagaimana Allah (Pencipta dan Penguasa alam semesta) dan Yesus Kristus (Juruselamat) dalam meresponi realitas keberagamaan manusia, yaitu berupa perspektif dan tindakannya. ${ }^{41}$

Dengan demikian, Teologi Multikultural mampu menghadirkan prinsip-prinsip alkitabiah sebagai dasar relasi interpersonal maupun intercommunity dalam berkehidupan berbangsa, khususnya dalam kehidupan berpolitik di negeri yang plural ini. Sebab, Plural society mesti diubah menjadi multicultural society, agar dapat terwujudnya kesedarajatan dalam keanekaragaman.

\section{Allah sebagai Pencipta Multikultural}

Alkitab mencatat bahwa Allah menciptakan manusia pada hari keenam setelah Allah menciptakan ciptaan-ciptaan lainnya selama lima hari lamanya. Selanjutnya, Alkitab juga mencatat, "Baiklah Kita menjadikan manusia menurut gambar dan rupa Kita ... maka Allah menciptakan manusia itu" (Kej.1:26-27)." Istilah diciptakan segambar (imagio dei) dan serupa (similitudo dei) dengan Allah, memiliki arti bahwa manusia diciptakan dengan segala potensinya. Dengan tujuan, pertama, manusia dapat berelasi dengan Allah. Kedua, manusia sebagai wakil Allah di bumi ini dapat mengemban mandat budaya atas alam semesta. Ketiga, adanya relasi yang harmonis antara manusia dengan manusia, manusia dengan alam dan yang terpenting manusia dengan sang Pencipta. ${ }^{42}$ Terkait dengan segambar dan serupa, Sudarmanto menyatakan bahwa sebagai gambar dan rupa Allah, manusia telah menjadi mahluk sosial. Di mana manusia didesain untuk hidup berelasi dengan sesamanya dalam kehidupan bersama. ${ }^{43}$

Takkala Allah menciptakan manusia dalam 'kesegambaran' dan 'keserupaan' dengan semua potensi yang dimiliki oleh manusia, saat itu juga memampukan manusia menciptakan suatu kebudayaan (culture), dimana budaya merupakan hasil dari interaksi manusia dengan ciptaan-ciptaan yang lain di alam semesta. Kutipan dari Sir Edward Tailor yang terdapat dalam buku Christian Perspektif on Sociology, merumuskan kebudayaan sebagai berikut, "Culture is that complex whole includes knowledge, belief, art, morals, law, custom and any other capabilities and habits aquired

${ }^{40}$ Rustam Ibrahim, "Pendidikan Multikultural: Pengertian, Prinsip, Dan Relevansinya Dengan Tujuan Pendidikan Islam," Jurnal Addin, vol. 7, no. 1 (2013): 133; band. Will Kymlicka, "Mitsunderstanding Nationalism," in Theorizing Nationalism, ed. R. Beiner (Albany: State University of New York, 1999), 24.

${ }^{41}$ Gunaryo Sudarmanto, "Meretas Rancang Bangun Teologi Multikultural," Voice of Wesley: Jurnal Ilmiah Musik dan Agama, vol. 1, no. 1 (2019): 121-46, https://doi.org/10.36972/jvow.v1i1.6; Lihat juga, Nelly, "Book Review: Teologi Multikultural," PASCA: Jurnal Teologi Dan Pendidikan Agama Kristen 16, no. 1 (2020): 75-77, https://doi.org/10.46494/psc.v16i1.85.

${ }^{42}$ Hendra Rey, Manusia: Dari Penciptaan Sampai Kekekalan (Malang: Gandum Mas, 2002).

${ }^{43}$ Gunaryo Sudarmanto, Teologi Multikultural, 89-90. 
by man as member of society." 44 Selanjutnya rumusan tersebut dikembangkan oleh Horton dan Hunt Frederico menjadi sebagai berikut, "Culture is the learned and shared attitudes, values, and way of behaving of the members of society." 45

Kebudayaan, yang adalah akar kata dari multikultural, pada dasarnya adalah perintah Allah kepada manusia (Kej.1: 28). Tanggung jawab tetap dituntut Allah kepada manusia, tetap ada relasi antara ability dan responsibility. ${ }^{46}$ Dengan demikian, selain memiliki keistimewaan sebagai ciptaan, manusia juga dituntut bertanggungjawab untuk memelihara kebersamaan dengan sesamanya. Oleh karena itu, setiap manusia wajib dan bertanggung jawab untuk menjunjung tinggi kesederajatan dalam keberagaman yang telah Allah ciptakan. Tetapi sebaliknya, seseorang yang tidak menghormati atau menerima keberadaan orang lain yang berbeda, sama saja menolak eksestensi Allah sebagai pencipta manusia. Termasuk para elit politik yang 'memperalat' identitas sebagai alat berpolitik, dengan memperuncing perbedaan-perbedaan demi ambisi kekuasaan, adalah orang-orang yang tidak menghormati keberadaan Allah.

\section{Kedaulatan Allah atas Multikultural}

Istilah 'berdaulat' dalam bahasa Inggris adalah sovereign, sedangkan dalam Bahasa Latinnya adalah 'superanus' (above, over). Menurut Zaluchu, Kedaulatan Allah adalah 'Kedaulatan Allah adalah ajaran Alkitab bahwa segala sesuatu berada di bawah kekuasaan dan kendali Tuhan, dan tidak ada yang terjadi tanpa arah atau izin- Nya. Tuhan bekerja bukan hanya beberapa hal tetapi segala sesuatu sesuai dengan kehendak-Nya sendiri."

Selanjutnya Greene menjelaskan sebagaimana dikutip oleh Tarigan, bahwa di dalam kedaulatan-Nya Allah telah menyediakan dunia ciptaan untuk dikelola oleh manusia sebagai ekspresi mengasihi pribadi Allah dengan keseluruhan hidupnya. Di mana ciptaan tersebut menyediakan hal-hal untuk dikerjakan, contohnya lingkungan, waktu, tubuh, pikiran, dan hati dengan kemampuan dan potensi manusia sebagai saluran untuk mengekspresikan kasih manusia sebagai ciptaan kepada Allah dan sesama. ${ }^{48}$ Kemudian hal ini ditegaskan kembali oleh Sudarmanto di dalam bukunya Teologi Multikultural bahwa di dalam kedaulatan-Nya yang absolut melalui karyaNya, Ia yang telah merancangkan diversitas manusia ke dalam sebuah sistem alam semesta yang saling terikat dan mutual. ${ }^{49}$

Dengan demikian, Allah, Pencipta yang berdaulat penuh terhadap semua ciptaan-Nya, menghendaki manusia untuk mengerjakan kebaikan-kebaikan bagi semua ciptaan yang lain. Jika kebaikan yang Allah kehendaki untuk manusia perbuat, maka secara tidak langsung setiap manusia harus memberikan penghargaan terhadap sesama manusia, siapapun dia. Kedaulatan Allah atas ciptaan-Nya yang beragam inilah yang seharusnya menjadi ukuran kesederajatan setiap insan. Hal

44 Stepen Grunlan, ed., Christian Perspektif on Sociology (Grand Rapid, Michigan: Zondervan Publishing House, 1982), 47; dikutip oleh Lotnatigor Sihombing, Kultus Dan Kultur: Sikap Etis Kristen Terhadap Kebudayaan (Batu: Sekolah Tinggi Theologia “I-3,” 1997), 69.

${ }^{45}$ Grunlan, Christian Perspektif on Sociology; dikutip Sihombing, Kultus dan Kultur: Sikap Etis Kristen Terhadap Kebudayaan.

${ }^{46}$ Sihombing, Kultus Dan Kultur: Sikap Etis Kristen Terhadap Kebudayaan, 79

47 Sonny Eli Zaluchu, "Penderitaan Kristus Sebagai Wujud Solidaritas Allah Kepada Manusia," Dunamis: Jurnal Teologi dan Pendidikan Kristiani, vol. 2, no. 1 (2017): 61-74.

48 A.E. Greene, Reclaiming the Future of Christian Education: A Transforming Vision (Colorado Springs: Association of Christian Schools International, 1998), 107; dikutip oleh Musa S. Tarigan, "Kebenaran Allah Sebagai Dasar Pendidikan Kristen," JOHME: Journal of Holistic Mathematics Education, vol. 3, no. 1 (2019): 90.

${ }^{49}$ Gunaryo Sudarmanto, Teologi Multikultural, 93. 
ini patut disadari dan dipahami oleh para elite politik, bahwa terciptanya perbedaan dan keberagaman adalah atas dasar kedaulatan Allah yang kekal dan absolut.

\section{Solidaritas dan Identifikasi Diri Kristus Sebagai Dasar Multikultural}

Peristiwa kejatuhan manusia dalam dosa mengakibatkan terjadi pemberontakan dua arah, yaitu pemberontakan terhadap Allah dan menciptakan perseteruan dengan sesama ciptaan. Manusia di dalam keberdosaannya, bertindak sebagai penguasa atas segala mahluk ciptaan. Keterpisahannya dengan Allah menjadikan dirinya semakin jahat dan terus mengalami penderitaan. Yesaya 59:2 menegaskan bahwa manusia terpisah dari Allah oleh karena dosanya dan saat itu juga manusia berjalan di dalam penderitaan. Zaluchu mengutip perkataan Agustinus yang mengatakan bahwa dosa adalah representasi kesombongan manusia. Di mana manusia sesungguhnya adalah mahluk yang dependen, ingin melepaskan diri dari kebergantungan tersebut dan ingin berusaha 'berdiri' sendiri tanpa Allah, namun tidak berdaya apapun. ${ }^{50}$ Berdasarkan realita tersebut, Allah telah menyiapkan a grand design bagi dunia yang 'terkutuk' oleh dosa ini. Allah telah mempersiapkan Anak-Nya yang tunggal, Yesus Kristus, untuk menebus manusia dari dosa, menggantikan manusia yang ada di dalam kutuk maut dengan penderitaan Kristus di kayu salib. Semua dilakukan Allah supaya manusia berdosa dapat berdamai kembali dengan diri-Nya. ${ }^{51}$

God's grand design tersebut merupakan wujud solidaritas Allah kepada manusia. Paulus di dalam surat Roma 8: 18-30, memberikan gambaran tentang penderitaan ilahi di dalam penebusan. Menurut Siahaan, Allah melalui Roh-Nya hadir bersama-sama manusia, merasakan penderitaan dan menyampaikan keluhan-keluhan manusia yang tak terucap kepada Allah (Rm.8:28). Inilah salah satu bukti kesolidaritasan Allah terhadap manusia yang sedang mengalami penderitaan di dunia. ${ }^{52}$

Ditambahkan juga oleh Ryken, Wilhoit dan Longman seperti yang dikutip Zaluchu: "bahwa Allah telah terlebih dahulu merasakan penderitaan yang lebih berat melalui kematian anak-Nya. Penderitaan yang berpuncak di dalam diri Yesus merupakan kisah tentang Allah yang menanggungkan penderitaan dunia kepada dirinya sendiri." ${ }^{53}$ Solidaritas Yesus multikultural yang menyeluruh dan holistik juga diperlihatkan dalam sepanjang pelayanan-Nya. Kasih yang sama Yesus tunjukkan pada semua golongan etnis. Baik pada orang Yahudi, orang Samaria maupun non Yahudi. ${ }^{54}$

Selain solidaritas Allah dalam Yesus kepada manusia, Identifikasi diri Yesus di dunia pun merupakan rangkaian yang tidak terpisahkan. Peterson memberikan gambaran mengenai Identifikasi Yesus, sebagai berikut: "On the cross, Jesus identified with us, taking the consequences of our sin. 'Identification' is a spiritual principle.... Knowing that Jesus died for our sins and believing on him for forgiveness will get you saved and 'born again'. Jesus identified with us

${ }^{50}$ Darrow L. Miller, Membangun Bangsa Dengan Pikiran Allah (Jakarta: YPPM, 2000), 188; dikutip oleh Zaluchu, "Penderitaan Kristus Sebagai Wujud Solidaritas Allah Kepada Manusia.", 65.

${ }^{51}$ Zaluchu, "Penderitaan Kristus Sebagai Wujud Solidaritas Allah Kepada Manusia.", 65.

${ }^{52}$ Harls Evan Siahaan, "Mengajarkan Nasionalisme Lewat Momentum Perayaan Paskah: Refleksi Kritis Keluaran 12: 1-51," DUNAMIS: Jurnal Teologi Dan Pendidikan Kristiani, vol. 1, no. 2 (2017): 39-54, www.sttintheos.ac.id/e- journal/index.php/dunamis.; band. Zaluchu, "Penderitaan Kristus Sebagai Wujud Solidaritas Allah Kepada Manusia.", 71.

${ }^{53}$ Leland Ryken, James C. Wilhoit, Tremper Longman III, Kamus Gambaran Alkitab (Surabaya: Penerbit Momentum, 2011), 241; dikutip oleh Zaluchu, "Penderitaan Kristus Sebagai Wujud Solidaritas Allah Kepada Manusia.”, 71.

${ }^{54}$ Yonatan Arifianto, "Deskripsi Sejarah Konflik Horizontal Orang Yahudi Dan Samaria,” PASCA : Jurnal Teologi Dan Pendidikan Agama Kristen, vol. 16, no. 1 (2020): 33-39, https://doi.org/10.46494/psc.v16i1.73. 
spiritually and physically in his death on the Cross and so spiritual and physically, he bore our sin and our shame." Seperti yang tercatat di di Galatia 2: 20, "I have been crucified with Christ and I no longer live, but Christ lives in me. The life I now live in the body, I live by faith in the Son of God, who loved me and gave himself for me. (NIV)". ${ }^{55}$ Untuk menginterpretasikan ayat ini, Peterson kembali menjelaskan, "Even in the natural, people become like who they identify with. If our identity is based on our cultural heritage, that's what we become like. If we identify with a particular sport or sports star, we become like them; we wear the same uniform as them and share in their wins and losses." $" 56$

Melalui penjelasan mengenai prinsip Solidaritas dan Identifikasi diri Yesus diharapkan dapat menjadi pegangan bagi setiap orang dalam memahami sebuah kebersamaan dalam keberagaman di bumi Indonesia ini. Tindakan inkarnatif Yesus, pelayanan-Nya yang bersifat holistik tanpa memandang latar belakang manusia, dan kematian-Nya Di kayu salib dan kuasa kebangkitan-Nya yang Ia kerjakan demi semua umat manusia berdosa, menjadi dasar teologis yang kuat untuk membentuk sikap seseorang dalam menghargai sesama manusia. Terlebih dalam proses berdemokrasi, tidak ada alasan lagi bagi elite-elite politik untuk 'memberdaya' perbedaan etnis maupun religi sesama sebagai alat politik kotornya.

\section{Universalitas Kasih Allah dalam Multikultural}

Masuk pada prinsip Teologi Multikultural berikutnya yakni Universalitas kasih Allah. Berbicara perihal kasih Allah, berarti berbicara mengenai karya keselamatan yang Allah kerjakan bagi setiap manusia. Manusia dapat diselamatkan dari maut hanya oleh Anugerah Allah melalui karya Kristus di kayu salib. ${ }^{57}$

Dalam Kamus Besar Bahasa Indonesia mencatat Istilah universal berarti "umum (berlaku untuk semua orang atau untuk seluruh dunia); bersifat (melingkupi) seluruh dunia." 58 Yohanes 3: 16 tertulis: "Karena begitu besar kasih Allah akan dunia ini, sehingga Ia telah mengaruniakan AnakNya yang tunggal, supaya setiap orang yang percaya kepada-Nya tidak binasa, melainkan beroleh hidup yang kekal." Jelas bahwa di ayat ini frase "setiap orang' berarti Allah mengasihi 'dunia' (manusia di dunia) secara universal atau Allah mengasihi dunia yang universal. Yang digarisbawahi di sini adalah tawaran keselamatan tersebut berlaku kepada dunia yang tidak terbatas hanya bangsa Israel saja, tetapi juga kepada bangsa di luar Israel. ${ }^{59}$ Dengan kata lain, cakupan keselamatan keluar dari keeksklusifan Israel.

Ariarajah memberikan contoh dari Alkitab bagaimana bangsa di luar Israel Alkitab juga boleh mendapatkan belas kasihan dari Allah, yaitu peristiwa pertobatan bangsa Niniwe di kitab Yunus. Ia menjelaskan bagaimana keselamatan itu berlaku juga kepada bangsa non-Israel atau penganut agama non-Yahudi, sebuah konsep kasih Allah yang universal. ${ }^{60}$ Menurut Martins, "Kitab Yunus

55 Grant Peterson, "Identifying With Jesus," Redeemer Coast Church, 2018, accessed April 20, 2020,https://www.redeemercoast.church/blog/identity.

56 Peterson. "Identifying With Jesus,"

${ }^{57}$ Harun Hadiwijono, Iman Kristen (Jakarta: BPK Gunung Mulia, 1995), 261.

58 "Universal," Kamus Besar Bahasa Indonesia (KBBI) Kamus versi online/ dalam jaringan, 2017, accessed April 20, 2020, https://kbbi.web.id/universal.

59 “Keselamatan,” Sarapan Pagi Biblika Ministry, 2015, accessed April 20, 2020, http://www.sarapanpagi.org/keselamatan-vt7679.html.

${ }^{60}$ Ariarajah Wesley, Alkitab Dan Orang-Orang Berkepercayaan Lain (Jakarta: BPK Gunung Mulia, 2009); "Keselamatan," dalam Wikipedia: Ensiklopedia Bebas, last modified 2017, accessed April 23, 2020, https://id.wikipedia.org/wiki/Keselamatan_(Kristen). 
melukiskan kedaulatan Allah yang mutlak atas seluruh ciptaan. Dalam kisah Niniwe, Allah digambarkan sebagai Allah yang rahami dan mengasihi lebih suka mengampuni daripada menghancurkan. ${ }^{\prime 11}$ Menurut Doeka, Allah telah mendengarkan pertobatan raja dan bangsa Niniwe melalui pemberitaan Yunus tentang penghukuman, tanpa memilih atas dasar bangsa pilihan atau tidak. Kemurahan hati Allah akan mengangkat siapapun yang mau bertobat ke dalam posisi yang pantas. ${ }^{62}$ Hal yang ingin diperlihatkan dalam kitab Yunus adalah kemurahan Allah dalam bentuk keselamatan tidak dibatasi oleh satu bangsa atau pribadi tertentu, namun kepada semua tanpa dibatasi oleh identitas apapun. Kepedulian Allah terhadap kota dan bangsa asing sama dengan kepada bangsa Israel dan kota Yerusalem. Demikian juga dengan doa dan pertobatan mereka, mendapat perhatian yang sama dari Allah.

Jika prinsip universalitas kasih Allah ini dimiliki oleh para elite politik, maka dapat dipastikan tidak ada lagi yang berani melakukan 'penghakiman' terhadap kelompok lain di luar kelompoknya. Setiap orang Kristen harus mewaspadai kecenderungan tersebut. Keragaman dalam kelompokkelompok masyarakat jangan menjadi penghalang untuk mengasihi sesama seperti mengasihi diri sendiri (Mat.22:39). Sebagaimana Allah mengasihi siapapun, sebagai ciptaan-Nya pun wajib mengasihi sesama tanpa dihalangi oleh identitas yang berbeda.

\section{Figur Politisi Multikultural}

Berangkat dari realitas berdemokrasi yang mempolitisasi identitas partikular beserta ancamannya, dan penanaman prinsip-prinsip Teologi Multikultural, maka dapat dibuat sebuah figur politisi yang dapat merepresentasikan figur politisi yang berjiwa multikutural. Berikut beberapa model politisi yang multikultural.

\section{Politisi yang Memiliki Spiritualitas}

Pada hakikatnya, spiritualitas adalah nilai sebuah kesadaran bahwa ada kekuatan dan kuasa yang lebih besar di atas keberadaannya sebagai manusia. Tentunya kuasa dan kekuatan besar tersebut adalah Allah yang menciptakan dan menguasai alam semesta, kesadaran tersebut diwujudkan dengan tindakan baik kepada sesama, alam dan kehidupan. ${ }^{63}$ Seorang politisi wajib memiliki spiritualitas yang baik. Kompetensi spiritualitas yang mapan akan memposisikan politisi tersebut sebagai teladan bagi masyarakat. Dapat dibayangkan jika seorang politisi mengabaikan aspek spiritualitas, maka dirinya akan membenarkan segala cara demi memenuhi ambisi politiknya. Terlebih dunia perpolitikan di Indonesia, seakan-akan memberi angin segar terhadap praktik-praktik politik yang menyimpang. Terkhusus meresponi tren politik identitas yang semakin hari semakin 'menciderai' kemurnian dari tujuan demokrasi di Indonesia. Keberagaman identitas (ras dan agama) menjadi instrumen para politisi 'jahat' dalam memainkan politiknya. Suwarta mengutip pernyataan dari Peter Canisius Aman, menurutnya keterlibatan agama dalam politik sangat riskan dan berbahaya jika agama dipolitisasi dan dieksploitasi oleh syahwat politik kelompok-kelompok tertentu. Tentu

${ }^{61}$ E.A. Martins, Plot and Purpose in the Old Testament (USA: Varsity Press, 1981); "Keselamatan," 2017.

62 Fredrik Y.A. Doeka, "Merajut Ke-Indonesia-an Yang Multikultural Dalam Pandangan Gereja Knitting Multicultural Indonesia in the Church's View," Millah: Jurnal Studi Agama, vol. 18, no. 2, Studi Agama-Agama (2018): 18.

63 I. Ivtzan, "Linkinng Religion and Spirituality with Psychological Well-Being: Examining Self Actualization, Meaning in Life, and Personal Growth Initiative," Journal of Religion and Health (2011); dikutip oleh Yulmaida Amir ac et al., "Religiusitas Dan Spiritualitas: Konsep Yang Sama Atau Berbeda?," Jurnal Ilmiah Penelitian Psikologi: Kajian Empiris \& Non-Empiris, vol. 2, no. 2 (2016): 70. 
tindakan tersebut sangat bertentangan denga cita-cita luhur politik. Agama yang seyogyanya membawa kedamaian akhirnya menimbulkkan kebrutalan untuk kepentingan politik yang picik dan kotor. Oleh karena itu, prinsip yang terpenting adalah bagaimana spiritualitas agama menjadi sumber inspirasi bagi para politisi dalam berpolitik. Jika spiritualitas tersebut dimiliki oleh setiap politisi, maka wajah perpolitikan di Indonesia akan jauh lebih bermartabat dan beradab. ${ }^{64}$ Sesuatu yang harus dipahami oleh setiap politisi yang hadir dan tinggal di bumi multikutural ini.

Penting untuk disadari bahwa bangsa yang beradab adalah bangsa yang mampu memposisikan nilai-nilai spiritualitas pada posisi terhormat atau tertinggi. Jika dilihat dari Dasar negara Indonesia, Pancasila, dalam sila pertama tertuliskan: "Ketuhanan yang maha Esa", itu berarti aspek spiritual adalah hal yang paling penting. Terlebih untuk mengurusi sebuah negara yang menjunjung tinggi nilai-nilai agama. Suwarta menambahkan, "Politisi yang memiliki spiritualitas adalah merekamereka yang sudah selesai dengan dirinya sendiri dan sepenuhnya mengabdi bagi kepentingan dan kebaikan bersama." ${ }^{65}$ Nilai spiritual yang baik yang dimiliki oleh seorang politisi akan membawanya kepada suatu pemahaman bahwa, perbedaan dan keberagaman adalah anugerah yang telah Allah berikan bagi kehidupan manusia dan betapa Allah sangat mengasihi semua manusia, tanpa melihat asal usulnya.

\section{Politisi yang Mengedepankan Dialog}

Salah satu krisis dunia yang paling mengancam saat ini adalah konsep berpikir tentang apa itu hidup dan hubungan antar sesama manusia. Dibutuhkan upaya untuk menghasilkan pengertian yang benar atas ancaman tersebut, oleh karena itu dialog merupakan upaya yang tepat, terlebih di konteks plural seperti Indonesia. Pengertian dialog sendiri adalah upaya untuk menjembatani bagaimana gesekan-gesekan bisa dihindari. Dialog antar umat beragama atau antar etnis merupakan sarana yang efektif menyelesaikan konflik. ${ }^{66}$ Terkait dengan hal ini Lukito menuturkan bahwa semua sikap intoleran dan fanatisme harus disingkirkan dan selalu mengedepankan dialog, didasarkan pada kesadaran adanya 'kompetisi' dalam cara pandang di masyarakat yang plural ini. ${ }^{67}$

Seorang politisi yang hadir di negeri yang majemuk ini, mesti menyadari bahwa dialog harus menjadi bagian terdepan untuk 'mengikat' keragaman tersebut. Namun yang harus menjadi perhatian adalah di dalam dialog wajib menghindari 'paksaan' agar dapat menerima perbedaan pandangan. Oleh karena itu, elemen-elemen yang harus ada adalah keterbukaan, persahabatan, kasih, respek dan toleransi. ${ }^{68}$ Terlebih dalam dialog antar umat beragama, diadakan bukan untuk meleburkan agamaagama menjadi satu atau sinkretisme, sikap menganggap agama tertentu sebagai yang paling benar, atau meniadakan perbedaan agama-agama. ${ }^{69}$ Dalam tindakannya, seorang politisi multikultural dalam dialog antar umat agama dan etnis harus memperhatikan beberapa hal, yaitu menghindari sikap menghina keyakinan atau agama lain; berusaha fleksibel ketika bertemu dengan orang yang memiliki

64 Thomas Harming Suwarta, "Politik Butuh Spiritualitas, Bukan Agama," Media Indonesia, 2019, accessed April 20, 2020, https://mediaindonesia.com/read/detail/238358-politik-butuh-spiritualitas-bukanagama.

65 Thomas Harming Suwarta. "Politik Butuh Spiritualitas, Bukan Agama,"

${ }^{66}$ Raihan Ghalib Muwaffaq, Dialog Antar Umat Beragama (Bandung, 2018), 7.

${ }^{67}$ Daniel Lukas Lukito, Rupa-Rupa Angin Pengajaran: Pergumulan 30 Tahun Membaca Arah Angin Teologi Kekinian (Malang: Literatur SAAT, 2017), 149.; Bandingkan P.L. Berger, A Rumor of Angels: Modern Society and the Rediscovery of Supernatural (Garden City: Doubleday, 1969), 42.

68 Lukito, Rupa-Rupa Angin Pengajaran: Pergumulan 30 Tahun Membaca Arah Angin Teologi Kekinian, 174.

${ }^{69}$ Muwaffaq, Dialog Antar Umat Beragama, 8. 
kepercayaan yang lain; bersikap bijak untuk mewujudkan relasi positif berdasarkan kesamaan; dan mengembangkan sikap yang baik dalam berdialog dengan orang dari kelompok lain. ${ }^{70}$

Dengan demikian, dengan mengedepankan dialog yang benar, politisi multikultural mampu menghadirkan atmosfer berbangsa dan bernegara yang baik. Dengan dialog dapat menghilangkan kecurigaan satu sama yang lain, persaudaraan akan semakin kuat oleh karena dilandasi oleh pengertian dan pengenalan, dan diharapkan dari dialog tersebut adalah hadirnya sikap toleransi antara kelompok yang mayoritas dan minoritas.

\section{Politisi yang Toleran Positif dan Saling Menerima}

Perlu untuk diketahui bahwa secara sederhana istilah toleransi kerap mengacu kepada sikap peaceful coexistance atau mampu hidup damai bersama dengan sesama tanpa mempersoalkan perbedaan-perbedaan identitas. Pada konteks bangsa Indonesia yan heterogen, penerapan nilai-nilai toleransi merupakan cara cerdas untuk memelihara kerukunan dan soliditas sesama anak bangsa. Sebaliknya, sikap intoleran dengan pola pikir yang sempit justru akan mendistorsi warisan budaya yang rukun dan damai, bersedia menjadi alat arogansi sektoral dan claim truth secara sepihak. ${ }^{71}$

Selain itu, sosok Kyai Abdurrahman Wahid atau dikenal dengan Gusdur mengemukakan hal toleransi sebagai berikut: "bukankah demikian menjadi jelas bagi kita bahwa menerima perbedaan pendapat dan asal muasal bukanlah tanda kelemahan, melainkan menunjukkan kekuatan dan tidak penting apa pun agamamu atau sukumu. Kalau kamu bisa melakukan sesuatu yang baik untuk semua orang, orang tidak pernah menanyakan apa agamamu." 72 Dari pernyataan tersebut menunjukkan bahwa sangat penting menjunjung tinggi sikap toleransi.

Politisi yang berjiwa multikultural wajib memiliki sikap toleransi dalam berpolitik. Sikap toleransi dan bisa menerima keberadaan orang lain adalah bukti kedewasaan dan keluasan berpikir seorang politisi. Searah dengan penjelasan Alie berkenaan dengan pembahasan etika dan moral politisi dalam buletin Parlementaria, menuturkan bahwa kedewasaan para politisi diukur dari bagaimana ia melihat mozaik bangsa Indonesia tersebut dibangun di atas diversity bangsa ini. Persatuan dalam sebuah frame kebangsaan akan menjadi landasan berpolitik anak bangsa. Di mana semua itu telah dibuktikan dalam perjalanan sejarah republik ini, yang dimulai dari keberhasilan founding fathers membawa Indonesia ke gerbang kemerdekaan. Oleh karena itu, eksistensi negara ini harus terus berjalan dengan menjalin kolektivitas di tengah heterogenitas, tanpa mengorbankan keberagaman. ${ }^{73}$

Untuk itulah politisi yang multikultural wajib menghadirkan kehidupan keragaman yang damai dan kondusif, melalui adanya toleransi positif. Semuanya itu mustahil akan terwujud jika kecurigaankecurigaan terhadap kelompok yang berbeda masih ada atau bahkan terus dipelihara. ${ }^{74}$ Sikap toleransi dan saling menerima orang lain yang dimiliki oleh para politisi bertujuan agar nilai-nilai yang terdapat dalam persatuan dan kesatuan Indonesia menjadi penghayatan setiap individual demi

\footnotetext{
${ }^{70}$ Lukito, Rupa-Rupa Angin Pengajaran: Pergumulan 30 Tahun Membaca Arah Angin Teologi Kekinian.

${ }^{71}$ Syahirul Alim, "Membangun Toleransi Politik," Kompasiana.Com, 2017, accessed April 20, 2020, https://www.kompasiana.com/syahirulalimuzer/589c252920afbdc31190afff/membangun-toleransi-politik.

${ }^{72}$ M. Diyan Saifudin, "Pentingnya Toleransi Dalam Berbangsa Dan Bernegara," Islampers.Com, 2019, accessed April 20, 2020, https://www.islampers.com/2019/08/pentingnya-toleransi-dalam-berbangsa.html.

73 Marzuki Alie, "Politisi Beradab Yang Menjunjung Etika Dan Moral," Buletin Mingguan Parlementaria (Jakarta, 2011), 3.

${ }^{74}$ Victor I. Tanja, Spiritualitas, Pluralitas dan Pembangunan di Indonesia (Jakarta: BPK Gunung Mulia, 1996), 3-4.
} 
pertanggungjawaban kepada sejarah Indonesia, dan kepada seluruh rakyat, dan kepada Allah Pencipta yang menciptakan keberagaman.

\section{Politisi yang Menjunjung Tinggi Nilai Solidaritas Nasionalis}

Secara umum pengertian solidaritas adalah: "sikap kesetiakawanan atau kebersamaan, dalam kepentingan bersama serta rasa simpati terhadap suatu kelompok tertentu. Solidaritas muncul ketika individu merasa cocok terhadap individu yang lain yang akhirnya melahirkan sebuah kesepakatan bersama untuk saling berkomitmen dalam suatu tujuan." ${ }^{75}$ Solidaritas kebangsaan mesti dibangun dari sebuah kesadaran bahwa negeri yang beragam kultur ini membutuhkan nilai-nilai kebersamaan, kepedulian dan keutuhan. Dengan solidaritas, maka ancaman-ancaman yang berpotensi menghancurkan persatuan bangsa bisa dihadapi bersama. Di mana kunci dari solidaritas sendiri adalah, pengorbanan. Shidarta mengutip pernyataan Ernest Renan, ia mengemukakan bahwa bangsa Indonesia akan mampu bertahan sebagai bangsa yang besar, jika nilai-nilai pengorbanan masih ada di tengah-tengah kebersamaan. Hal ini diyakini masih dimiliki oleh bangsa ini, terlihat ketika kekerasan, diskriminasi bahkan tindakan brutal yang dilakukan kelompok intoleran terhadap kelompok minoritas, mendapat perlawanan bersama dari masayarakat. ${ }^{76}$

Perlu disadari bahwa manusia pada hakikatnya adalah makhluk sosial yang sangat membutuhkan sesamanya. Realita multikultural yang ada di bumi indonesia membuktikan bahwa indonesia memiliki keragaman yang sangat membutuhkan nilai-nilai solidaritas nasionalis antara sesama anak bangsa demi hadirnya kehidupan yang harmonis.

Nilai-nilai pengorbanan sendiri telah dibuktikan melalui karya inkarnatif Yesus, Ia hadir dan mengorbankan dirinya untuk manusia berdosa. Green mengatakan sebagai berikut: "Kerajaan Allah telah datang melalui kehadiran dan karya Tuhan Yesus yang menyentuh seluruh aspek kehidupan manusia. Solidaritas-Nya didemonstrasikan melalui tindakan nyata. Ketika Ia berinteraksi dengan orang-orang non Yahudi, orang-orang Samaria, 'orang-orang berdosa,' para penderita kusta, dan yang lainnya. Yesus menerobos pagar-pagar pemisah yang selama ini telah terbangun selama beberapa waktu di dalam kehidupan Yahudi." 77

Nilai-nilai inilah yang mesti dimiliki oleh para politisi yang hadir di negara yang plural. Sehingga kehadiran politisi-politisi yang berjiwa solidaritas nasionalis mampu menghadirkan persatuan di negeri ini.

\section{Politisi yang Mampu Menghadirkan 'Shalom' Bagi Bangsa Indonesia}

Model politisi yang terakhir ini adalah sebuah panggilan gereja di tengah bangsa Indonesia. Sebagai politisi, tugas untuk menghadirkan shalom adalah tugas utama bagi semua orang beriman, tugas yang berangkat dari teladan Sang Guru Agung, Yesus Kristus. Dalam eksistensinya Yesus disebut Raja shalom (Yes. 9:5).

Sepanjang Yesus mengerjakan karya dan pelayanan-Nya, Ia mengajarkan sesuatu yang sangat penting yaitu menghadirkan damai sejahtera bagi siapapun pada waktu itu: bagaimana Ia

75 Mifdal Zusron Alfaqi, "Memahami Indonesia Melalui Perspektif Nasionalisme, Politik Identitas, Serta Solidaritas," Jurnal Pendidikan Pancasila dan Kewarganegaraan, vol. 28, no. 2 (2015): 113, http://journal.um.ac.id/index.php/jppk/article/view/5451/2120.

76 Shidarta, "Solidaritas Besar Bangsa Indonesia," BINUS University; Faculty of Humanities, 2016, accessed April 20, 2020, https://business-law.binus.ac.id/2016/12/23/solidaritas-besar-bangsa-indonesia/.

77 Joel B. Green, Memahami Injil-Injil Dan Kisah Para Rasul (Jakarta: Persekutuan Pembaca Alkitab, 2005), 178 
menyampaikan Kabar Baik kepada golongan-golongan sosial yang terpinggirkan (Luk.4:18-19). Aksi memberi makan kepada orang-orang yang lapar (Mrk.8:1-10; Mat.15:32-39). Yesus juga membebaskan dan memulihkan orang yang dikuasai roh setan (Mat. 8:28-34; Mrk.5:1-18; Luk. 8:26-37). Bahkan dicatat di bagian yang lain bahwa Yesus mengidentikkan diri-Nya sebagai orangorang yang menderita. Oleh karena itu, Yesus menegaskan bahwa apapun yang kita perbuat kepada orang-orang yang lemah tersebut, sesungguhnya kita telah melakukan kepada diri-Nya. ${ }^{78}$

Menurut Behman, hidup berdampingan dengan kelompok mayoritas di negeri ini sesungguhnya terdapat opportunity dan challange tersendiri dalam mengabarkan shalom tersebut. Dengan kata lain, semakin berat dan besar tantangan tersebut, semakin memberikan peluang besar dalam menghadirkan shalom. Oleh karena, Kristus telah menganugerahkan damai sejahtera yang sejati. "Damai sejahtera yang Tuhan berikan kepada kita bukan dengan perang, ketakutan, dan kekhawatiran. Namun, damai sejahtera sejati yang penuh pengorbanan seperti apa yang Kristus berikan." ${ }^{79}$ Dengan demikian, perintah menghadirkan shalom bagi sesama di konteks masyarakat majemuk ini harus menjadi panggilan utama dalam kehidupan politisi. Tidak hanya dislogankan, tetapi harus diupayakan dalam pelayan publik.

\section{KESIMPULAN}

Tren politik identitas di dalam praktiknya, memperalat 'kelompok-kelompok' partikular demi kepentingan elite-elite politik yang tidak bertanggungjawab. Tren tersebut kemudian direspon dengan Teologi Multikultural untuk menghadirkan persatuan, keadilan dan kesejahteraan bagi rakyat indonesia. Politik identitas yang dipakai untuk meraih simpati dan dukungan massa, selalu berakhir pada benturan-benturan di masyarakat. Strategi berpolitik tersebut dapat mengorbankan rakyat sendiri.

Oleh karena itulah Teologi Multikultural hadir untuk memberikan edukasi dan prinsipprinsip dalam berdemokrasi, yang mengakui dan mengedepankan kesetaraan atau kesederajatan insan manusia berdasarkan kajian-kajian Firman Allah. Teologi Multikultural berupaya mengkorelasikan aspek iman kepada Allah dengan realitas kehidupan bersama dalam mewujudkan demokrasi yang adil dan sejahtera. Selain itu Teologi Multikultural tetap menegaskan identitas kekristenan, yaitu keunikan dan finalitas Kristus sebagai pemberitaan kabar keselamatan yang dibutuhkan oleh rakyat Indonesia yang multikultural ini.

\section{REFERENSI}

Ahsanti, Afik. "Teologi Multikultural: Telaah Atas Pemikiran Tokoh Indonesia Komarudin Hidayat." Yogyakarta, 2015.

Alfaqi, Mifdal Zusron. "Memahami Indonesia Melalui Prespektif Nasionalisme, Politik Identitas, Serta Solidaritas." Jurnal Pendidikan Pancasila Dan Kewarganegaraan 28, no. 2 (2015): 111-16.

Alie, Marzuki. "Politisi Beradab Yang Menjunjung Etika Dan Moral.” Buletin Mingguan Parlementaria. Jakarta, 2011.

\footnotetext{
${ }^{78}$ Kalis Stevanus, "Mengimplementasikan Pelayanan Yesus Dalam Konteks Misi Masa Kini Menurut Injil Sinoptik,” FIDEI: Jurnal Teologi Sistematika dan Praktika, vol. 1, no. 2 (2018): 289-290.

79“"Kekristenan Yang Menghadirkan Shalom,” E-Bahana (Yogyakarta, February 2019).
} 
Alim, Syahirul. "Membangun Toleransi Politik." Kompasiana.Com, 2017.

Amir ac, Yulmaida, Diah Rini Lesmawati Psikologi, Fakultas Psikologi, and Universitas RI Muhammadiyah Hamka Kementerian Sosial. "Religiusitas Dan Spiritualitas: Konsep Yang Sama Atau Berbeda?" Jurnal Ilmiah Penelitian Psikologi: Kajian Empiris \& Non-Empiris 2, no. 2 (2016): 67-73.

Arifianto, Yonatan. "Deskripsi Sejarah Konflik Horizontal Orang Yahudi Dan Samaria." PASCA : Jurnal Teologi Dan Pendidikan Agama Kristen 16, no. 1 (2020): 33-39. https://doi.org/10.46494/psc.v16i1.73.

Baidi. “Agama Dan Multikulturalisme : Pengembangan Kerukunan Masyarakat Melalui Pendekatan Agama." Millah, 2010.

Bawaslu. "Potensi Penggunaan Suku, Agama, Ras Dan Antar Golongan Dalam Pemilihan Kepala Daerah Serentak 2018." Jakarta, 2017.

Berger, P.L. A Rumor of Angels: Modern Society and the Rediscovery of Supernatural. Garden City: Doubleday, 1969.

Casram. "M EMBANGUN SIKAP TOLERANSI BERAGAMA," no. August (2016). Chaplin, James P. Kamus Lengkap Psikologi. Terjemahan. Jakarta: Raja Grafindo Persada, 2011.

Clark, M. Eisenstein \& A. "Explaining Differing Democratic Norm Commitment: Rethinking the Religion- Psychological Security-Democratic Norm Support Connection." Politics and Religion 10, no. 4 (2017): 753-85. https://doi.org/10.1017/S175504831700030X.

Debora Sanur L. "Rekonsiliasi Politik Identitas Di Indonesia." Majalah Info Singkat. Jakarta, May 2017.

Doeka, Fredrik Y A. "Merajut Ke-Indonesia-an Yang Multikultural Dalam Pandangan Gereja Knitting Multicultural Indonesia in the Church's View." Millah : Jurnal Studi Agama 18, no. Studi Agama-Agama (2018): 15-30. https://doi.org/10.20885.

Donald L. Morowitz. "Demokrasi Pada Masyarakat Majemuk." In Nasionalisme, Konflik Etnik Dan Demokrasi, edited by Mars F Plattner and Larry Diamond. Bandung: ITB Pres, 1998. E.A. Martins. Plot and Purpose in the Old Testament. USA: Varsity Press, 1981.

Emilianus Yakob Sese Tolo. "Di Bawah Bayang-Bayang Ahok: Politik Identitas Dalam Pemilu Di NTT.” Tirto.Id, 2019.

Erikson, Millar J. Teologi Kristen Vol. 1. Malang: gandum Mas, 2004.

Felix Nathaniel. "Politik Identitas Tetap Buas, Masyarakat Bawah Kena Imbas." Tirto.Id, 2019. Fernandez, MG Noviarizal. "Politik Identitas Merusak Demokrasi," 2019.

Frame, John M. Systematic Theology: An Introduction to Christ Belief. New Jersey: P \& R, 2013. Geertz, Cifford. "Religion in Java; Conflict and Integration." In Sociology of Religion: Selected Readings, edited by Roland Robertson, 165-217. England: Penguine Book, 1971.

Green, Joel B. Memahami Injil-Injil Dan Kisah Para Rasul. Jakarta: Persekutuan Pembaca Alkitab, 2005.

Greene, A.E. Reclaiming the Future of Christian Education: A Transforming Vision. Colorado Springs: Association of Christian Schools International, 1998.

Grunlan, Stepen, ed. Christian Perspektif on Sociology. Grand Rapid, Michigan: Zondervan Publishing House, 1982.

Habibi, Muhammad. "Analisis Politik Identitas Di Indonesia (Identity Politics in Indonesia).” Samarinda, 2017.

Haboddin, Muhtar. "Menguatnya Politik Identitas Di Ranah Lokal." Studi Pemerintahan 3, no. 2012 (2012): 116-34. 
Hadiwijono, Harun. Iman Kristen. Jakarta: BPK Gunung Mulia, 1995.

Herdiansah, Ari Ganjar. "Politisasi Identitas Dalam Kompetisi Pemilu Di Indonesia Pasca 2014." Jurnal Bawaslu 3, no. 2 (2017): 169-83.

Ibrahim, Rustam. "Pendidikan Multikultural: Pengertian, Prinsip, Dan Relevansinya Dengan Tujuan Pendidikan Islam.” Jurnal Addin 7, no. 1 (2013): 129-54.

Idris Hemay and Aris Munandar. "Politik Identitas Dan Pencitraan Kandidat Gubernur Terhadap Perilaku Pemilih.” Jurnal Politik: Kajian Politik Dan Masalah Pembangunan 12, no. 1 (2016): 37-48.

Ivtzan, I. "Linkinng Religion and Spirituality with Psychological Well-Being: Examining Self Actualization, Meaning in Life, and Personal Growth Initiative." Journal of Religion and Health, 2011. https://doi.org/10.1007/s10943-011-9540-2.

J.L. Sullivan; G.E. Marcus; J.E.Piereson. "An Alternative Conceptualization of Political ToleRance: Illusory Increases 1950s- 1970s.” The American Political Science Review 73, no. 2 (1979): 781-94. https://doi.org/10.2307/1955404.

"Kekristenan Yang Menghadirkan Shalom.” E-Bahana. Yogyakarta, February 2019.

"Keselamatan." Sarapan Pagi Biblika Ministry, 2015.

"Keselamatan." Wikipedia: Ensiklopedia Bebas, 2017.

Kymlicka, Will. "Mitsunderstanding Nationalism." In Theorizing Nationalism, edited by R. Beiner, 24. Albany: State University of New York, 1999.

Leland Ryken, James C. Wilhoit. Kamus Gambaran Alkitab. Surabaya: Penerbit Momentum, 2011. Lili Romli. "Political Identity and Challanges for Democracy Consolidation in Indonesia." Jurnal

Politik Indonesia 4, no. 1 (2019).

Lukito, Daniel Lukas. Rupa-Rupa Angin Pengajaran: Pergumulan 30 Tahun Membaca Arah Angin Teologi Kekinian. Malang: Literatur SAAT, 2017.

Maarif, Ahmad Syafii. Politik Identitas Dan Masa Depan Pluralisme Kita. Edited by Martin Sinaga. 1st ed. Jakarta: Democracy Project, 2012.

Macquarrie, John. Principle of Christian Theology. London: SCM Press, 1996.

Mietzner, M. "Reinventing Asian Populism: Jokowi's Rise, Democracy, and Political Contestation in Indonesia. Policy Studies," 2015.

Miller, Darrow L. Membangun Bangsa Dengan Pikiran Allah. Jakarta: YPPM, 2000.

Muwaffaq, Raihan Ghalib. "Dialog Antar Umat Beragama." Bandung, 2018.

Nasrudin, Juhana. "Politik Identitas Dan Identitas Kebangsaan.” Al-Karimah 05, no. 09 (2018): 94 137.

Nelly. "Book Review: Teologi Multikultural." PASCA: Jurnal Teologi Dan Pendidikan Agama Kristen 16, no. 1 (2020): 75-77. https://doi.org/10.46494/psc.v16i1.85.

Novalina, Martina. "Spiritualitas Orang Kristen Dalam Menghadirkan Kerajaan Allah Di Tengah Tantangan Radikalisme.” Jurnal Teologi Kontekstual Indonesia 1, no. No.1 (2020): 26-37. https://doi.org/10.46445/jtki.v1i1.293.

Parekh, Bikhu. (Terj) Rethinking Multiculturalism, Keragaman Budaya Dan Teori Politik.

Yogyakarta: Kanisius, 2008.

Peterson, Grant. "Identifying With Jesus." Redeemer Coast Church, 2018.

Pratama, Erlangga. "Politik Identitas: Ancaman Dalam Pilkada 2020.” Jurnal Intelijen.Net: Verba Volant Scripta Manent, 2020.

Rey, Hendra. Manusia: Dari Penciptaan Sampai Kekekalan. Malang: Gandum Mas, 2002.

Ronda, Daniel. Dasar Teologi Yang Teguh: Panduan Teologi Sistematika Di Perguruan Tinggi. I. 
Makasar: STT Jaffray, 2013.

Ryrie, Charles C. Teologi Dasar 1. Yogyakarta: ANDI, 2017.

Saifudin, M. Diyan. "Pentingnya Toleransi Dalam Berbangsa Dan Bernegara." Islampers.Com, 2019.

Saputra, Muhammad Ali. "Menguatnya Politik Identitas Dan Problem Kerukunan Beragama Di Manokwari." Mimikri 3 (2017): 15-27.

Sari, Endang. "Kebangkitan Politik Identitas Islam Pada Arena Pemilihan Gubernur Jakarta." Kritis 2, no. 2 (2016): 145-56.

Shidarta. "Solidaritas Besar Bangsa Indonesia." BINUS University; Faculty of Humanities, 2016.

Siahaan, Harls Evan. "Mengajarkan Nasionalisme Lewat Momentum Perayaan Paskah: Refleksi Kritis Keluaran 12: 1-51.” DUNAMIS: Jurnal Teologi Dan Pendidikan Kristiani 1, no. 2 (2017): 39-54.

Sihombing, Lotnatigor. Kultus Dan Kultur: Sikap Etis Kristen Terhadap Kebudayaan. Batu: Sekolah Tinggi Theologia "I-3," 1997.

Stevanus, Kalis. "Mengimplementasikan Pelayanan Yesus Dalam Konteks Misi Masa Kini Menurut Injil Sinoptik.” Fidei: Jurnal Teologi Sistematika Dan Praktika 1, no. 2 (2019): 284-98. https://doi.org/10.34081/270036.

Sudarmanto, Gunaryo. "Meretas Rancang Bangun Teologi Multikultural." Voice of Wesley: Jurnal Ilmiah Musik Dan Agama 1, no. 1 (2019): 121-46. https://doi.org/10.36972/jvow.v1i1.6.

- Teologi Multikultural. Edited by Dina Elisabeth Latumahina. 1st ed. Batu: Departemen Multi-Media YPPII Batu, 2014.

Sudarsono, Juwono. Pembangunan Politik Dan Perubahan Politik. Pertama. Jakarta: Gramedia, 1976.

Susanto, Happy. “Kritisisme Sejarah Teologi Barat.” Tsaqafah 7, no. 2 (2011): 299. https://doi.org/10.21111/tsaqafah.v7i2.11.

Tanja, Victor I. Spiritualitas, Pluralitas Dan Pembangunan Di Indonesia. Jakarta: BPK Gunung Mulia, 1996.

Tarigan, Musa S. "Kebenaran Allah Sebagai Dasar Pendidikan Kristen.” JOHME: Journal of Holistic Mathematics Education 3, no. 1 (2019): 80-95. https://doi.org/https://dx.doi.org/10.19166/johme.v3i1.1684 Vol.

Thomas Harming Suwarta. "Politik Butuh Spiritualitas, Bukan Agama." Media Indonesia, 2019. "Universal." Kamus Besar Bahasa Indonesia (KBBI) Kamus versi online/ dalam jaringan, 2017. Wesley, Ariarajah. Alkitab Dan Orang-Orang Berkepercayaan Lain. Jakarta: BPK Gunung Mulia, 2009.

Zaluchu, Sonny. "Penderitaan Kristus Sebagai Wujud Solidaritas Allah Kepada Manusia." DUNAMIS: Jurnal Penelitian Teologi Dan Pendidikan Kristiani 2, no. 1 (November 4, 2017): 61. https://doi.org/10.30648/dun.v2i1.129.

Zaluchu, Sonny Eli. "Strategi Peneltian Kualitatif Dan Kuantitatif Di Dalam Penelitian Agama." Evangelical 4, no. 1 (2020): 28-38.

Zhafira, Ananda. "Efek Moderasi Kepercayaan Politik Terhadap Hubungan Antara Religiusitas Islam Dan Intoleransi Politik.” Jurnal Psikologi Sosial 15, no. 2 (2017): 122-35. https://doi.org/10.7454/jps.2017.11. 